\title{
Polar Bear Distribution and Abundance on the Southwestern Hudson Bay Coast During Open Water Season, in Relation to Population Trends and Annual Ice Patterns
}

\author{
IAN STIRLING ${ }^{1,2}$ N.J. LUNN,${ }^{1}$ JOHN IACOZZA,${ }^{3}$ CAMPBELL ELLIOTT ${ }^{4}$ and MARTYN OBBARD ${ }^{5}$
}

(Received 3 August 2002; accepted in revised form 6 June 2003)

\begin{abstract}
In Hudson Bay, all the ice melts in summer, and the last areas to be ice-free (around mid-to-late July) are usually off the coasts of Manitoba and Ontario. Thus, all polar bears are forced ashore to fast until freeze-up in November (ca. four months). Pregnant females remain ashore for eight months. In most years from 1963 through 1997, aerial surveys to monitor polar bear populations were conducted along all or part of the coastline between Cape Churchill, Manitoba, and Cape Henrietta Maria, Ontario, in late August and early September. Satellite data, from which breakup and ice absence times could be estimated, first became available in 1971. The numbers of animals counted were tallied in two subareas within Manitoba and three within Ontario. We evaluated the coastal counts, along with independent data on the movements of tagged bears and annual patterns of ice breakup from 1971 through 1996. We concluded that 1) the coastal survey data reliably indicated the population trends in Manitoba and Ontario; 2) little exchange occurred between the Western Hudson Bay (Manitoba) and Southern Hudson Bay (Ontario) populations; 3) between 1971 and 2001, there was a statistically significant trend toward earlier breakup of sea ice off the Manitoba coast, but not off the Ontario coast; 4) the onset of ice absence along the coast had no significant relationship to the number of bears present in each sub-sampling area within either the Manitoba or the Ontario population, but did significantly influence the distribution of bears on the coastline of each province independently of the other; 5) timing of the surveys can influence the results; and 6) adult male and female bears both showed a high degree of fidelity to specific areas during summer, independent of the pattern of ice breakup.
\end{abstract}

Key words: aerial survey, Hudson Bay, sea ice, breakup, polar bears, Ursus maritimus, Manitoba, Ontario, arctic climate

RÉSUMÉ. Dans la baie d'Hudson, toute la glace fond en été, et les dernières zones à être non englacées (du milieu à la fin de juillet environ) se trouvent généralement au large des côtes du Manitoba et de l'Ontario. Ainsi, tous les ours polaires sont forcés de rester sur la terre ferme et de jeûner jusqu'à l'engel en novembre (soit environ quatre mois). Les femelles gravides, elles, restent sur la terre ferme pendant huit mois. Presque chaque année entre 1963 et 1997, à la fin août et au début de septembre, on a effectué des relevés aériens pour surveiller les populations d'ours polaires le long du littoral entre Cape Churchill, au Manitoba, et Cape Henrietta-Maria, en Ontario. Les données satellitaires, qui ont permis d'estimer la période de la débâcle et celle de l'absence de glace, sont devenues disponibles à partir de 1971. Le nombre d'animaux repérés a été inventorié comme provenant de deux souszones à l'intérieur du Manitoba et de trois à l'intérieur de l'Ontario. On a évalué le dénombrement des relevés côtiers ainsi que des données indépendantes sur les déplacements d'ours marqués et les schémas annuels de débâcle de 1971 à la fin de 1996. On en a conclu que: 1) les données des relevés côtiers révélaient de façon fiable les tendances démographiques au Manitoba et en Ontario; 2) il n'y avait que peu d'échanges entre les populations de la baie d'Hudson occidentale (Manitoba) et de la baie d'Hudson méridionale (Ontario);3) entre 1971 et 2001, il y a eu une tendance statistiquement significative à une débâcle précoce au large du littoral manitobain, mais pas au large du littoral ontarien; 4) le début de l'absence de glace le long de la côte n'avait pas de lien marqué avec le nombre d'ours présents dans chaque secteur de sous-échantillonnage, au sein de la population du Manitoba ou de celle de l'Ontario, mais cette absence de glace avait une forte incidence sur la distribution des ours le long de la côte de chaque province indépendamment l'une de l'autre; 5) le choix de l'époque des relevés peut influencer les résultats; et 6), durant l'été, les ours mâles comme femelles manifestaient une grande fidélité pour des secteurs spécifiques, indépendamment de l'évolution de la débâcle.

Mots clés: relevé aérien, baie d'Hudson, glace de mer, débâcle, ours polaires, Ursus maritimus, Manitoba, Ontario, climat arctique

Traduit pour la revue Arctic par Nésida Loyer.

\footnotetext{
${ }^{1}$ Canadian Wildlife Service, 5320-122nd Street, Edmonton, Alberta T6H 3S5, Canada

${ }^{2}$ Corresponding author: ian.stirling@ec.gc.ca

${ }^{3}$ Centre for Earth Observation Science (CEOS), Department of Geography, University of Manitoba, Winnipeg, Manitoba R3T 2N2, Canada

${ }^{4}$ Manitoba Conservation, Box 28, 59 Elizabeth Drive, Thompson, Manitoba R8N 1X4, Canada; present address: Parks Canada Agency, P.O. Box 127, Churchill, Manitoba R0B 0E0, Canada

${ }^{5}$ Wildlife Research and Development Section, Ontario Ministry of Natural Resources, 300 Water Street, 3rd Floor North, P.O. Box 7000, Peterborough, Ontario K9J 8M5, Canada

(c) The Arctic Institute of North America
} 


\section{INTRODUCTION}

During the open water season in Hudson Bay, from about mid-July through mid-November, polar bears (Ursus maritimus) are distributed along the coastlines of Manitoba and Ontario and on the islands of James Bay, adjacent to where the last of the annual ice typically breaks up (Jonkel et al., 1976; Stirling et al., 1977; Prevett and Kolenosky, 1982; Derocher and Stirling, 1990; Kolenosky et al., 1992). Although there may be considerable overlap in the distribution of animals during winter and spring, while they are hunting seals on the sea ice, individual bears show a sufficient degree of fidelity to the coastal areas of Manitoba or Ontario to facilitate delineation of two distinct populations for management purposes, the Western Hudson Bay (WH) and Southern Hudson Bay (SH) populations (Derocher and Stirling, 1990; Kolenosky et al., 1992; Stirling and Derocher, 1993; Taylor and Lee, 1995; Stirling et al., 1999). These populations share a common boundary that approximates the border between the two provinces (Fig. 1).

Once on shore, bears of different age and sex classes vary in their habitat preferences, choosing different terrestrial habitats in different geographic areas. In Manitoba, north of the Nelson River, large adult males predominate along the coast. In contrast, pregnant adult females, most adult females accompanied by dependent young, and subadults move farther inland, probably to avoid possible predation by adult males. In the inland areas, they spend the summer along the relatively dry and vegetated banks of lakes and streams (Stirling et al., 1977; Derocher and Stirling, 1990; Clark and Stirling, 1998). In contrast, on the coast of Manitoba south of the Nelson River and in northern Ontario, subadults and females accompanied by dependent young (but not pregnant females) are regularly found along the coastal plain (Kolenosky et al., 1992; Lunn et al., 1997). It seems likely that fewer bears of these latter age and sex groups go inland south of the Nelson River, possibly because so much more of the area adjacent to the coast is flat and marshy. In comparison to the area between the Nelson and Churchill Rivers to the north, there appear to be few exposed dry hummocks or raised lake edges with frozen peat banks in which dens can be dug or on which bears might be able to rest where they can be cooled by wind. Also, in the area north of the Nelson River, polar bears that are inland from the coast commonly feed on berries of Vaccinium uliginosum and Empetrum nigrum (Derocher et al., 1993). It may be that in areas north of the Nelson River such berry crops are more available, so that some bears, especially family groups, move inland to exploit these food sources. To date, however, there are not enough quantitative data with which to test either these or other possible hypotheses. Regardless of some of the geographic variation in age and sex composition, the regular and predictable presence of substantial numbers of polar bears along the coastlines of both Manitoba and Ontario during the open water season stimulated interest in trying to use annual aerial surveys of animals along the coast to monitor population trends.

Although there was variation among years in aircraft type and number of observers, the aerial surveys were repeated in as systematic and comparable a manner as possible (Stirling et al., 1977; Prevett and Kolenosky, 1982; C. Elliott and M. Obbard, unpubl. data). From examination of data in these published and unpublished surveys, it is clear that interannual variation exists in the total numbers counted in Manitoba and Ontario, both at the same time of year and through the open water season. Even so, Prevett and Kolenosky (1982) reported a roughly 50\% increase in the combined total for the two areas between 1967 and 1981. They also suggested that much of the variation in the number of animals counted in the two areas in different years (and in their distribution, especially near the Manitoba-Ontario border) was influenced by where the last ice broke up, thereby forcing the bears ashore. More specifically, they suggested that when counts in Manitoba were high, they were lower in Ontario, and vice versa, which they interpreted as indicating that there might be a greater amount of exchange between bears from the two populations than had previously been thought. However, subsequent analyses of mark-recapture data and movements of radio-collared bears did not support that hypothesis (Derocher and Stirling, 1990; Kolenosky et al., 1992; Lunn et al., 1997; Stirling et al., 1999).

Part of the difficulty in interpreting the results of aerial counts undertaken in both Manitoba and Ontario is that past examinations of the data have not considered all sources of information at the same time (e.g., Stirling et al., 1977; Prevett and Kolenosky, 1982). Thus, for this paper, wherever possible, we evaluated all the coastal survey data available on polar bears from both Manitoba and Ontario (1963-1997) in relation to available data on the timing of ice breakup and absence (1971-2001) and the movements of tagged and radio-collared bears (1984-2001). Our goal was to test two hypotheses: 1) that the pattern of breakup determines the initial distribution and abundance of polar bears along the western and southern coastline of Hudson Bay and 2) that the number of bears counted in the coastal surveys over time reflects population trends.

Previous studies in western Hudson Bay and elsewhere have shown that adult female polar bears show a high degree of fidelity to maternity denning areas (e.g., Ramsay and Stirling, 1990; Amstrup and Gardner, 1994) and have demonstrated a strong relationship between the time of breakup and the date and location where adult females come ashore (Stirling et al., 1999).

Although data from mark-recapture studies indicate adult male polar bears and subadults of both sexes also have a strong degree of fidelity to the coastal areas of Manitoba and Ontario, we thought it possible that these latter two groups might be more flexible about where they came ashore than either pregnant females or females accompanied by dependent young because their fidelity to coastal areas might not be as strong as the fidelity of adult 


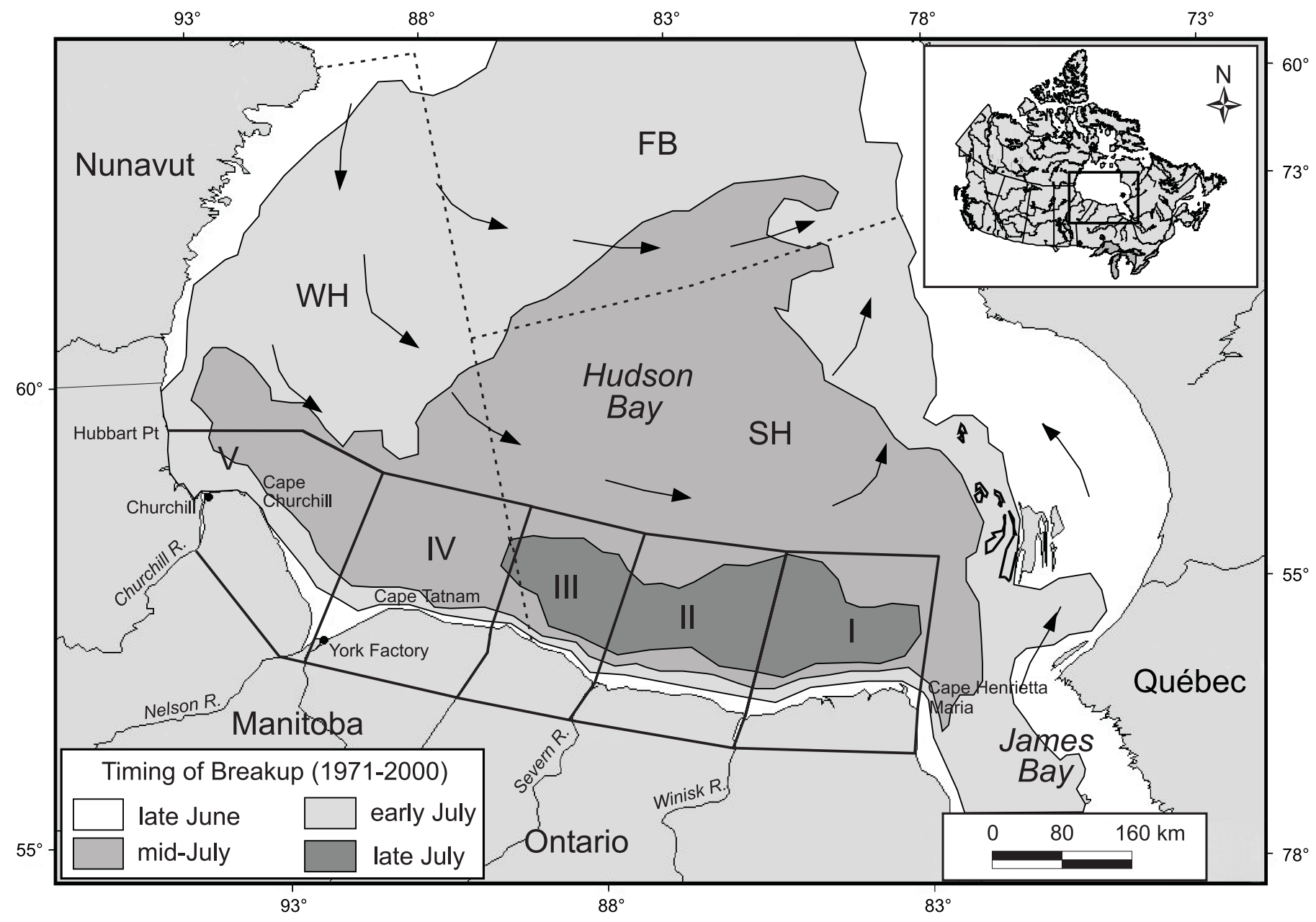

FIG. 1. Hudson Bay, showing polar bear population boundaries (FB: Foxe Basin; SH: Southern Hudson Bay; WH: Western Hudson Bay), coastal areas surveyed, and offshore areas used in the determination of breakup. Arrows indicate the general marine circulation pattern. Also shown are the 30-year average (1971-2000) dates of the geographic progression of breakup for the study area, based on weekly regional ice charts from the Canadian Ice Service.

females to denning areas. Consequently, we hypothesized that adult males and subadult bears would remain on the ice for longer than adult females, which, if true, might partially explain variation in the total numbers of bears reported in some years near the Manitoba-Ontario border (Prevett and Kolenosky, 1982).

\section{METHODS}

\section{Study Area}

The study area included over $1100 \mathrm{~km}$ of the coastline of western and southern Hudson Bay, from Hubbart Point, Manitoba, to Hook Point $\left(54^{\circ} 50^{\prime} \mathrm{N}, 82^{\circ} 12^{\prime} \mathrm{W}\right)$ on the James Bay coast, just east of Cape Henrietta Maria, Ontario (Fig. 1).

To facilitate analysis of the coastal survey data, we divided the Manitoba and Ontario coastline into five areas. Three of these were the same as those defined by Prevett and Kolenosky (1982) for the Ontario coast: Area 1 (Hook Point to the Winisk River), Area 2 (the Winisk River to the Severn River), and Area 3 (the Severn River to the Manitoba-
Ontario border). Since Lunn et al. (1997) had previously observed that the distribution of age and sex classes of bears along the Manitoba coast differed north and south of the Nelson River (Lunn et al., 1997), we divided that section into Area 4 (Manitoba-Ontario border to York Factory) and Area 5 (York Factory to Hubbart Point).

\section{Timing of Ice Breakup and Absence}

During winter, Hudson Bay is completely ice-covered. Breakup occurs first on the eastern coast followed by the northern areas (Stirling et al., 1977). A counterclockwise current in Hudson Bay, in concert with the prevailing winds, causes the last remaining ice in late spring or early summer to be distributed along the western and southwestern coasts (Markham, 1986; Prinsenberg and Freeman, 1986; Wang et al., 1994; Saucier et al., in press) (Fig.1). Consequently, the on-ice distribution of polar bears from the WH and SH populations is reduced from roughly the southern two-thirds of the entire bay in winter (Kolenosky et al., 1992; Stirling et al., 1999) to a residual area in the southwest by early summer (Fig. 1). Although the Manitoba 
coast is north of Ontario, the currents and wind continue to move the remaining ice south and then east, so that in most years the last annual ice to break up and melt lies along the coast of northern Ontario (Fig. 1).

The timing of breakup and subsequent absence of the residual annual ice in the five defined coastal sectors (Fig. 1) was determined from analysis of weekly sea ice concentration charts produced by the Canadian Ice Service (Canadian Ice Service, Environment Canada, Ottawa). These charts were available only from 1971 onwards, so that coastal counts collected before that date could not be included in the analyses of bear distribution in relation to ice breakup. The boundaries of the offshore areas adjacent to the coastal sectors were delineated subjectively after examination of a series of annual ice maps to determine where the last ice typically breaks up and melts. These areas extended $100-200 \mathrm{~km}$ offshore to cover the area in which most of the last ice usually remained before final breakup. To ensure that trends in the timing or pattern of breakup of the subareas of either Manitoba or Ontario were representative of the offshore areas used by the $\mathrm{WH}$ and SH polar bear populations (Fig. 1), we also calculated the time of breakup for each entire zone (as was done for $\mathrm{WH}$ in Stirling et al., 1999) for comparison.

Sea ice concentration values were given on a grid with $0.5^{\circ}$ latitude and longitude spacing. For each area, ice concentration values were averaged, starting from the last week of complete ice cover to the first week that the ice was gone (defined as being less than 1/10th ice cover). Following Etkin (1991), we defined breakup as the date by which half the total ice cover had disintegrated during the spring melt period to four-tenths concentration or less, while the other half was still five-tenths concentration or greater, giving a total ice cover of five-tenths. We plotted these values and interpolated the dates of both ice breakup and absence.

\section{Coastal Surveys}

From 1963 through 1996, annual surveys of the Ontario coast were flown in fixed-wing aircraft at an altitude of 150-200 m. Observers on both sides of the aircraft recorded all bears visible. Surveys were flown between 14 August (1968) and 14 September (1984) because it was assumed that all bears would be ashore by mid-August (Prevett and Kolenosky, 1982; M. Obbard, unpubl. data). In Manitoba, coastal surveys were flown in most years from 1965 through 1997, mostly by Bell 206B helicopter, at an altitude of 150-200 m with observers on both sides. They were flown between 20 August (1974) and 21 September (1967), usually in association with waterfowl surveys and checking on waterfowl hunters (Stirling et al., 1977; C. Elliott, unpubl. data).

However, the most important point with respect to comparability of the surveys is that most of the bears along the coast are found in a narrow band of beach ridges within a few hundred metres of the water. Thus, all the surveys
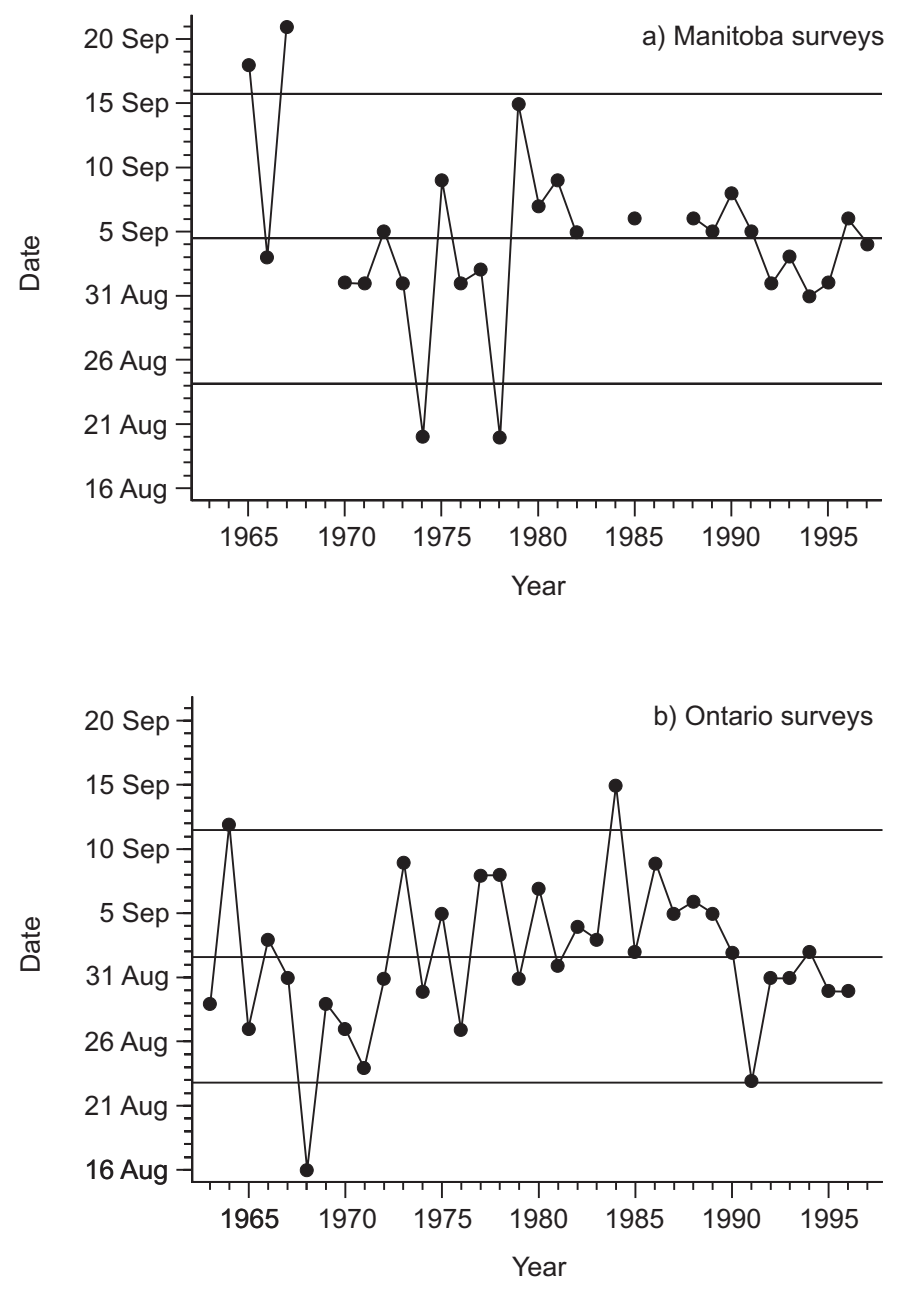

FIG. 2. Timing of aerial surveys along the coasts of (a) Manitoba and (b) Ontario, 1963-97. Horizontal lines represent the mean survey dates and the upper and lower $90 \%$ confidence limits.

were flown as a single continuous track over the same narrow band of coastline each year. Because white bears are so visible in a snow-free environment and the coastal strip within which most are likely to be seen is so narrow, most observers will see most of the bears most of the time, regardless of experience, minor differences in altitude flown, or the kind of aircraft used. This is what makes an "index" survey of this sort valuable for determining relative changes in distribution and abundance over time. Combined, these surveys provided uncorrected minimum counts of polar bears along the entire Manitoba and Ontario coastlines from Hubbart Point (MB) to Hook Point (ON) in most years between 1963 and 1997 (Table 2). Thus, while there was undoubtedly some variation between observers, we are confident the differences in distribution and abundance recorded between years are real.

All bears seen were counted and classified by age and sex class on each survey. However, even at moderate distances, experienced observers can confuse lone adult males with subadults, and it is not possible to distinguish subadult males from subadult or adult females reliably. Similarly, it can be difficult for an inexperienced observer 
TABLE 1. Chronology of ice breakup and absence in Hudson Bay in relation to coastal survey areas, 1971-2001. Means are shown together with their standard errors.

\begin{tabular}{|c|c|c|c|}
\hline & Area $1-3$ & Area 4 & Area 5 \\
\hline Mean date of ice breakup & 17 July \pm 2.0 days & 14 July \pm 2.1 days & 7 July \pm 2.7 days \\
\hline Earliest date of ice breakup & 6 June 1990 & 5 June 1990 & 2 June 1990 \\
\hline Latest date of ice breakup & 3 August 1985, 1986 & 30 July 1974 & 30 July 2000 \\
\hline Mean date of ice absence & 6 August \pm 3.0 days & 1 August \pm 2.3 days & 25 July \pm 2.6 days \\
\hline Earliest date of ice absence & 28 June 1999 & 23 June 1999 & 26 June 1999 \\
\hline Latest date of ice absence & 1 September 1992 & 24 August 1992 & 18 August 1992 \\
\hline
\end{tabular}

to distinguish cubs-of-the-year from yearling cubs correctly when they are accompanying an adult female. Consequently, we classified bears counted on each survey as either family groups (i.e., adult female accompanied by dependent young) or lone bears, because these categories could be reliably recorded.

The mean survey dates were 5 September \pm 1.3 days $(\mathrm{n}=27)$ for Manitoba and 2 September \pm 1.0 days $(\mathrm{n}=34)$ for Ontario (Fig. 2). Four Manitoba surveys (1965, 1967, 1974,1978 ) occurred on days that fell outside the $90 \%$ confidence interval of the mean survey date (25 August16 September), whereas three Ontario surveys (1964, $1968,1984)$ were flown on days that fell outside the $90 \%$ confidence interval (23 August - 12 September). Data from these seven surveys were not included in subsequent analyses. In addition, the 1993 Ontario data were excluded because poor weather precluded surveying the complete coastline. Lastly, we restricted the analysis of the relationship between bear distribution and breakup patterns to 1971 -96, the only years for which data on ice breakup and ice absence were available.

Stepwise multiple regression (Systat Version 10, SPSS Inc., Chicago, Illinois) was used to examine the effects of year, date of survey, date of ice breakup, date of ice absence, area, and their interactions on the coastal counts of polar bears. The initial regression model contained no explanatory variables. Each significant term $(p<0.05)$ was added, in turn, until all terms that significantly increased the explanatory power of the model were included. However, because the presence of some terms may mask the importance of others, we tested whether the subsequent inclusion of terms previously eliminated improved the model. The analysis was complete when the model could not be improved by either adding or deleting any term.

\section{Movements of Adult Male \& Female Bears between Years}

We compared the distance between capture and recapture locations, capture interval, and the annual variation in mean latitude of capture locations of 188 adult males and 236 adult females that had been previously handled and tagged as part of studies of the population ecology of polar bears in southern and western Hudson Bay (Kolenosky et al., 1992; Stirling et al., 1999; I. Stirling, N. Lunn, and M. Obbard, unpubl. data). Distance was determined by calculating the great circle distance between locations. In this
TABLE 2. Numbers of polar bears counted during annual aerial surveys of the Manitoba and Ontario coastlines in relation to coastal survey area.

\begin{tabular}{|c|c|c|c|c|c|c|c|}
\hline \multirow[b]{2}{*}{ Year } & \multicolumn{4}{|c|}{ Ontario } & \multicolumn{3}{|c|}{ Manitoba } \\
\hline & Area 1 & Area 2 & Area 3 & Total & Area 4 & Area 5 & Total \\
\hline 1963 & 17 & 7 & 23 & 47 & - & - & - \\
\hline 1964 & 12 & 0 & 13 & 25 & - & - & - \\
\hline 1965 & 14 & 3 & 26 & 43 & - & - & 32 \\
\hline 1966 & 15 & 4 & 21 & 40 & - & - & 35 \\
\hline 1967 & 84 & 40 & 26 & 150 & - & - & 29 \\
\hline 1968 & 35 & 22 & 34 & 91 & - & - & - \\
\hline 1969 & 18 & 9 & 38 & 65 & - & - & - \\
\hline 1970 & 59 & 7 & 56 & 122 & 22 & 39 & 61 \\
\hline 1971 & 31 & 11 & 31 & 73 & - & - & 141 \\
\hline 1972 & 63 & 17 & 34 & 114 & 27 & 69 & 96 \\
\hline 1973 & 29 & 16 & 26 & 71 & 31 & 130 & 161 \\
\hline 1974 & 32 & 11 & 20 & 63 & 25 & 119 & 144 \\
\hline 1975 & 69 & 19 & 29 & 117 & 31 & 65 & 96 \\
\hline 1976 & 35 & 7 & 24 & 66 & 42 & 104 & 146 \\
\hline 1977 & 75 & 10 & 38 & 123 & 22 & 95 & 117 \\
\hline 1978 & 29 & 30 & 62 & 121 & 53 & 83 & 136 \\
\hline 1979 & 85 & 31 & 42 & 158 & 14 & 51 & 65 \\
\hline 1980 & 93 & 21 & 59 & 173 & 13 & 98 & 111 \\
\hline 1981 & 75 & 15 & 93 & 183 & 29 & 56 & 85 \\
\hline 1982 & 78 & 11 & 47 & 136 & 0 & 172 & 172 \\
\hline 1983 & 66 & 11 & 72 & 149 & - & - & - \\
\hline 1984 & 89 & 25 & 20 & 134 & - & - & - \\
\hline 1985 & 58 & 32 & 26 & 116 & 39 & 30 & 69 \\
\hline 1986 & 57 & 11 & 33 & 101 & - & - & - \\
\hline 1987 & 49 & 9 & 36 & 94 & - & - & - \\
\hline 1988 & 45 & 23 & 75 & 143 & 11 & 115 & 126 \\
\hline 1989 & 59 & 36 & 66 & 161 & 94 & 81 & 175 \\
\hline 1990 & 129 & 63 & 44 & 236 & 39 & 63 & 102 \\
\hline 1991 & 87 & 27 & 45 & 159 & 94 & 81 & 175 \\
\hline 1992 & 52 & 22 & 37 & 111 & 50 & 94 & 144 \\
\hline 1993 & 103 & 54 & - & 157 & 51 & 115 & 166 \\
\hline 1994 & 170 & 21 & 63 & 254 & 57 & 78 & 135 \\
\hline 1995 & 171 & 22 & 47 & 240 & 49 & 67 & 116 \\
\hline 1996 & 85 & 60 & 56 & 201 & 36 & 104 & 140 \\
\hline 1997 & - & - & - & - & 59 & 74 & 133 \\
\hline
\end{tabular}

analysis, we restricted the data to those bears that were first captured in Area 5 because the time series was too short for bears handled in the other four areas. If a subsequent capture was made in one of the other areas, that movement was included in analyses. We also restricted the data to include only adult bears (males $\geq 5$ years of age, females $\geq 4$ years of age) that were handled in July, August, or September. After this time, bears begin to move in anticipation of freeze-up (Prevett and Kolenosky, 1982; Derocher and Stirling, 1990), so that locations of captures made after September may not reflect where the bears 

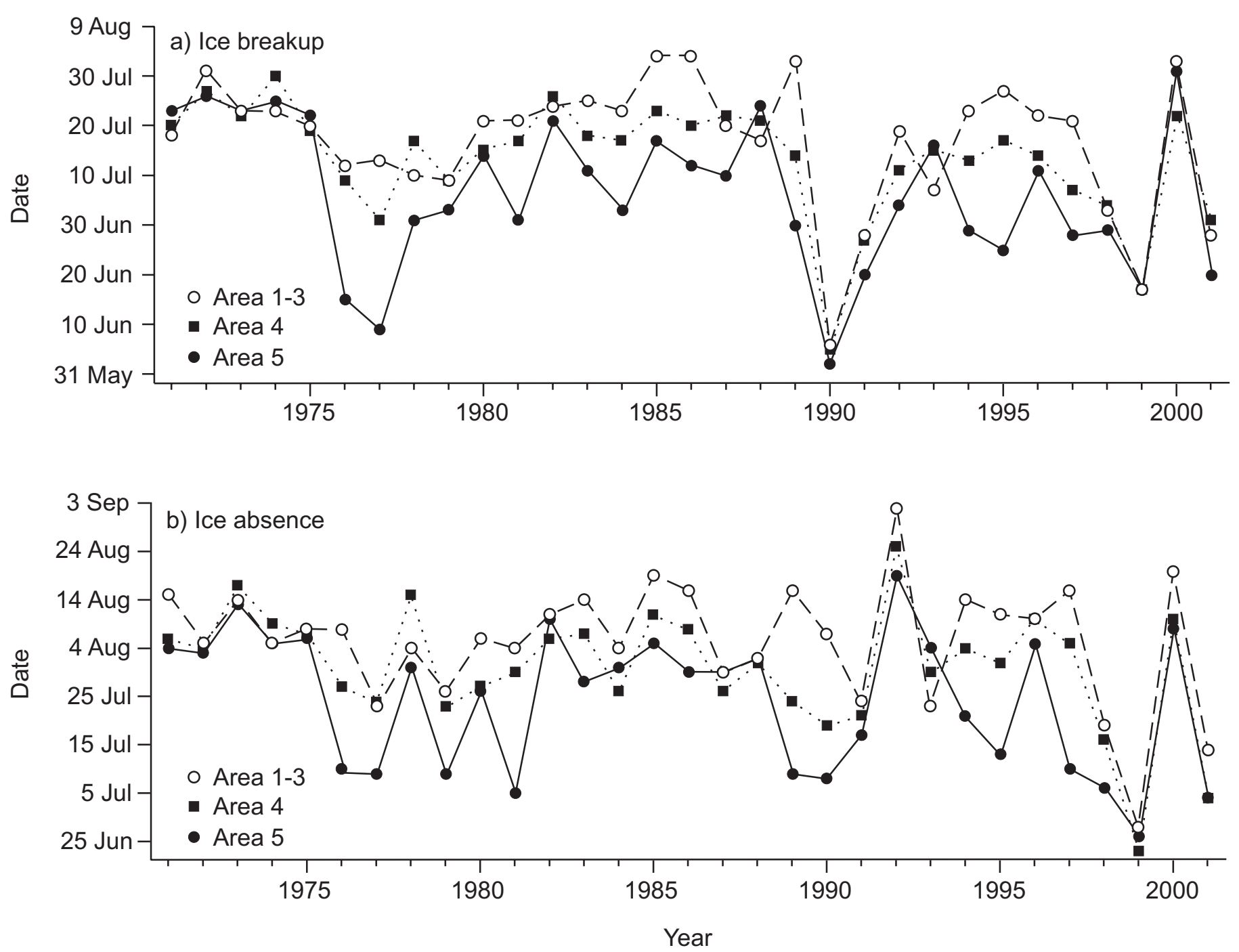

FIG. 3. Timing of sea ice (a) breakup and (b) absence on Hudson Bay, offshore of five survey areas along the coasts of Manitoba and Ontario, 1971-2001.

spent the summer. To determine whether there were sexspecific differences in capture locations, the annual mean capture latitude was calculated for a total of 722 and 945 captures of 384 individual adult males and 523 females, respectively, between 1984 and 2001.

\section{RESULTS}

Timing of Ice Breakup and Absence, 1971-2001

There were significant annual and regional differences in the timing of breakup (general linear model, year, $\mathrm{F}_{30,120}$ $=17.263, p<0.001 ;$ area, $\left.\mathrm{F}_{4,120}=15.725, p<0.001\right)$ (Table 1). Pairwise post-hoc comparisons (Bonferroni adjustment) of the timing of breakup revealed that there were no significant differences between Areas 1, 2, and 3 ( $p>0.05$ in all cases), so these areas were pooled. The time of breakup in Area 5 was significantly earlier than in all other areas ( $p<0.001$ in all cases). For time of breakup, Area 4 was not significantly different from Areas 1 or 2 $(p>0.15$ in both cases) but was significantly different from Area $3(p<0.015)$.

Similarly, there were significant annual and regional differences in the timing of ice absence (Table 1) $\left(\mathrm{F}_{30,120}=\right.$ $14.961, p<0.001$; area, $\left.\mathrm{F}_{4,120}=16.200, p<0.001\right)$. Again, pairwise post-hoc comparisons revealed that there were no significant differences between Areas 1, 2, and 3 ( $p>0.95$ in all cases) and that Area 5 was significantly different from all others $(p<0.005$ in all cases). For date of ice absence, Area 4 was not significantly different from Areas 1 or 3 ( $p>0.15$ in both cases) but was significantly different from Area $2(p=0.029)$.

Given that there were no significant differences in the timing of ice breakup or absence between Areas 1, 2, and 3 , these areas were combined (Area 1-3) for all subsequent analyses involving ice chronology.

In general, ice breakup and absence progressed from west to east, occurring earliest in Area 5 and latest in Area 1-3 (Table 1, Fig. 3). Breakup in the coastal sectors over the 31-year period (Fig. 1) has been occurring progressively earlier off the Manitoba coast (Spearman rank 

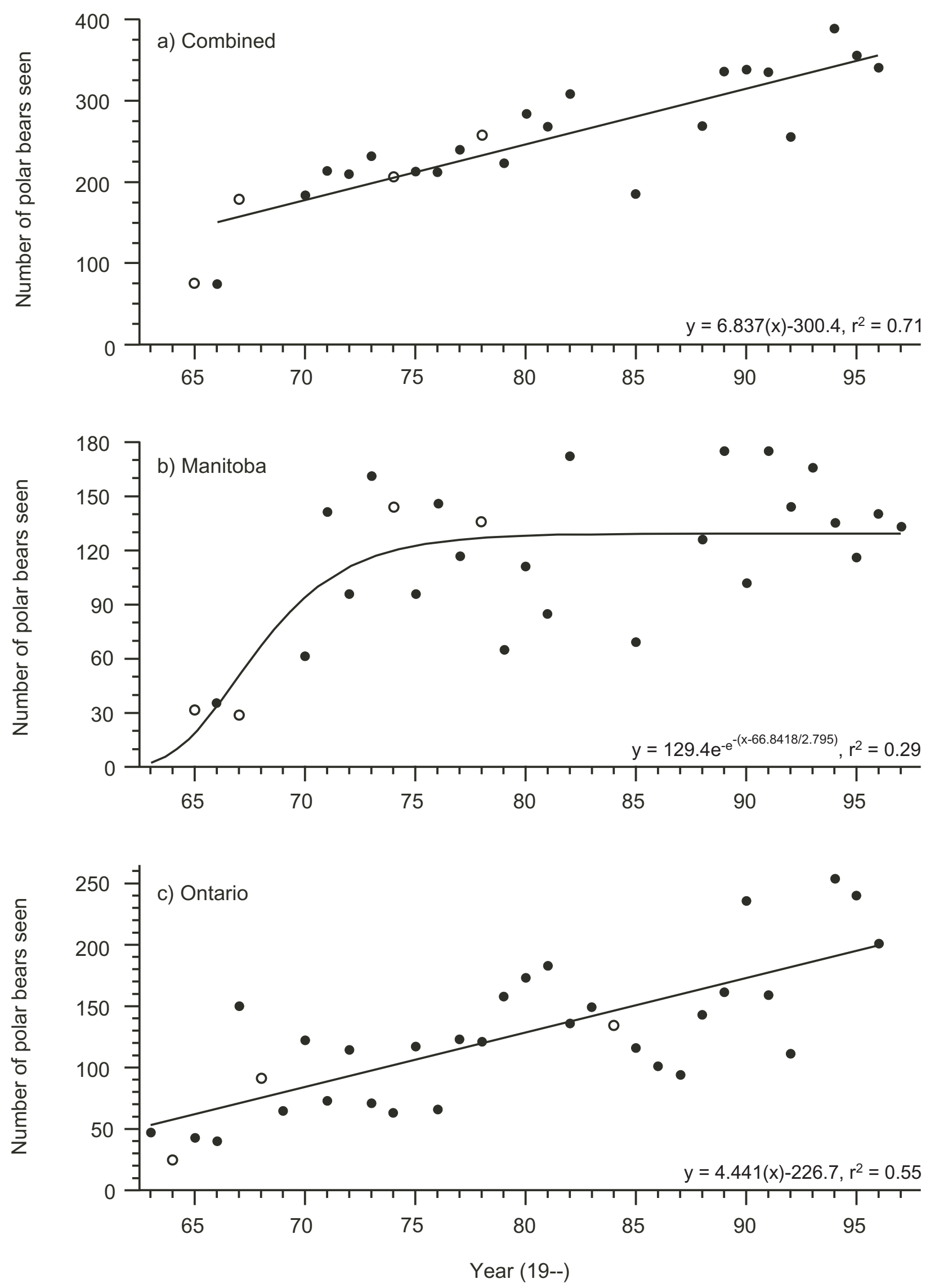

FIG. 4. Numbers of polar bears counted during aerial surveys along the Manitoba and Ontario coasts in relation to year (1963-97). Open circles represent counts not included in the regressions, from surveys flown on dates that fell outside of the $90 \%$ confidence interval of mean survey dates. 
TABLE 3. Multiple regression models describing the numbers of polar bears counted during coastal surveys of Manitoba and Ontario, 1971-97.

\begin{tabular}{|c|c|c|c|c|c|c|}
\hline & Term & Coefficient & $\mathrm{F}$ & df & $p$ & $\%$ variance explained \\
\hline \multirow[t]{5}{*}{ a) } & Manitoba coastal surveys $(n=40,86.8 \% \text { of variance explained })^{1}$ & & & & & \\
\hline & Constant & 771.955 & - & - & - & - \\
\hline & Area $\times$ Ice breakup & 7000.586 & 53.22 & 1 & $<0.001$ & 44.6 \\
\hline & Survey date & 31.662 & 10.49 & 1 & 0.0046 & 7.6 \\
\hline & Area $\times$ Year $\times$ Ice breakup $\times$ Ice absence & - & 2.50 & 19 & 0.0289 & 34.6 \\
\hline \multirow[t]{5}{*}{ b) } & Ontario coastal surveys $(n=72,71.6 \% \text { of variance explained })^{2}$ & & & & & \\
\hline & Constant & 84.334 & - & - & - & - \\
\hline & Area $\times$ Ice absence & - & 31.99 & 2 & $<0.001$ & 38.8 \\
\hline & Year $\times$ Ice absence & - & 2.24 & 23 & 0.0103 & 29.5 \\
\hline & Survey date - Ice absence & -1.417 & 5.31 & 1 & 0.0259 & 3.3 \\
\hline \multirow[t]{3}{*}{ c) } & Combined Manitoba and Ontario coastal surveys $(n=90,45.3 \%$ & variance expla & & & & \\
\hline & Constant & 55.795 & - & - & - & - \\
\hline & Area $\times$ Ice absence & - & 17.58 & 4 & $<0.001$ & 45.3 \\
\hline
\end{tabular}

${ }^{1}$ rejected terms $(p>0.05)$ from the Manitoba model: Area, Area $\times$ Ice absence, Ice absence - Ice breakup, Ice absence, Survey date - Ice absence, Ice breakup, Survey date - Ice breakup, Year, Year $\times$ Ice breakup, Year $\times$ Ice absence, and Year $\times$ Survey date.

${ }^{2}$ rejected terms $(p>0.05)$ from the Ontario model: Area $\times$ Ice breakup, Year, Year $\times$ Survey date, Ice absence, Survey date, Ice absence - Ice breakup, Survey date - Ice breakup, Ice breakup, Year $\times$ Ice breakup, Area, and Area $\times$ Year $\times$ Ice breakup $\times$ Ice absence.

${ }^{3}$ rejected terms $(p>0.05)$ from the Combined model: Survey date, Ice absence - Ice breakup, Area $\times$ Year $\times$ Ice breakup $\times$ Ice absence, Area, Ice breakup, Survey date - Ice breakup, Year $\times$ Ice absence, Survey date - Ice absence, Year $\times$ Survey date, Area $\times$ Ice breakup, Year, Year $\times$ Ice breakup, and Ice absence.

correlation, Area 4, $\mathrm{r}_{\mathrm{s}}=-0.472, \mathrm{df}=29, p=0.008$; Area 5, $\left.r_{\mathrm{s}}=-0.381, \mathrm{df}=29, p=0.034\right)$, but not off the Ontario coast (Pearson product-moment correlation, Area 1-3, $\mathrm{r}=264$, $\mathrm{df}=29, p=0.151)$. These results are consistent with a significant trend toward earlier breakup in the total area occupied through the winter by the WH bear population $(\mathrm{r}=0.497, \mathrm{df}=29, p=0.0044)$, as first reported by Stirling et al. (1999). Conversely, there was no significant trend in breakup in the total sea ice area occupied through the winter by the $\mathrm{SH}$ bear population $(\mathrm{r}=-0.252, \mathrm{df}=29, p=$ 0.172 ), which was consistent with the results from Area 13 . There was no trend in the timing of ice absence (Area 1$3, \mathrm{r}_{\mathrm{s}}=-0.058, \mathrm{df}=29, p=0.774 ;$ Area $4, \mathrm{r}_{\mathrm{s}}=-0.279, \mathrm{df}=$ 29, $p=0.127$; Area 5, $\mathrm{r}_{\mathrm{s}}=-0.304$, df $\left.=29, p=0.095\right)$.

\section{Trends in Total Numbers of Polar Bears Observed on Aerial Surveys, 1963-97}

There was considerable annual and regional variation in the numbers of bears counted along the coastlines of Ontario and Manitoba from 1963 to 1997 (Table 2). However, no significant correlations (positive or negative) were found between any of the Ontario area counts and any of the Manitoba area counts (Pearson product-moment correlations, $p>0.2$ in all cases) or between the total Ontario counts and the total Manitoba counts $(r=0.115$, df $=19, p=0.621)$.

The total number of polar bears counted along the Manitoba and Ontario coasts combined has increased over the 35 years that surveys have been flown (Pearson product-moment correlation, $\mathrm{r}=0.842, \mathrm{df}=19, p<0.001$; Fig. 4a). However, the trends in the counts over time were markedly different in Manitoba and Ontario. Along the Manitoba coast, the number of polar bears counted (Fig. 4b) increased from the mid-1960s through the mid1970 s, after which it remained relatively constant. This leveling off appeared to be largely influenced by the counts in Area 5, where there was no significant correlation with year $(\mathrm{r}=0.066, \mathrm{df}=19, p>0.75)$. Counts in Area 4 continued to increase over time $(r=0.532$, df $=19$, $p<0.015)$. Counts of bears along the Manitoba coast were best explained by a model (squared multiple $\mathrm{R}=0.868$ ) that contained one variable (Survey Date) and two interaction terms (Area $\times$ Date of Ice Breakup and Area $\times$ Year $\times$ Date of Ice Breakup $\times$ Date of Ice Absence) (Table 3a).

Along the Ontario coast, the number of animals counted continued to increase throughout the period of surveys $(\mathrm{r}=0.739, \mathrm{df}=28, p<0.001 ; \mathrm{Fig} .4 \mathrm{c})$. Year was positively correlated with counts of bears in Area $1(\mathrm{r}=0.667, \mathrm{df}=$ $29, p<0.001)$, Area $2(\mathrm{r}=0.568, \mathrm{df}=29, p<0.001)$, and Area $3(\mathrm{r}=0.491, \mathrm{df}=28, p<0.01)$. The model (squared multiple $\mathrm{R}=0.716$ ) that best explained the counts of bears along the Ontario coast (Table $3 \mathrm{~b}$ ) contained two interaction terms (Area $\times$ Date of Ice Absence and Year $\times$ Date of Ice Absence) plus the calculated variable Survey Date Date of Ice Absence.

Although the multiple regression model for the Ontario counts did not include Area as a significant explanatory variable, the number of bears counted in Area 1 was correlated with the number of bears counted in Area $2(r=0.495$, $\mathrm{df}=29, p<0.005)$ and in Area $3(\mathrm{r}=0.370, \mathrm{df}=28, p<0.05)$ when the complete dataset (1963-96) was analyzed. There was no significant correlation between the two Manitoba coastal areas $(r=-0.211, \mathrm{df}=19, p>0.35)$. 
TABLE 4. Summary of capture locations of adult male and female polar bears in northeastern Manitoba, 1984-2001.

\begin{tabular}{lcc}
\hline \hline & Adult Males & Adult Females \\
\hline Mean capture latitude (all years) & $58.176 \pm 0.015(\mathrm{n}=722)$ & $57.924 \pm 0.012(\mathrm{n}=945)$ \\
Most northerly capture year & $1984-86\left(58.800^{\circ} \mathrm{N}\right)$ & $1984\left(58.783^{\circ} \mathrm{N}\right)$ \\
Most southerly capture year & $1995\left(57.217^{\circ} \mathrm{N}\right)$ & $1996\left(57.083^{\circ} \mathrm{N}\right)$ \\
Range (all years) & 1.583 degrees latitude & 1.700 degrees latitude \\
Range in means (capture years) & 0.598 degrees latitude & 0.690 degrees latitude \\
\hline \hline
\end{tabular}

\section{Capture Locations and Movements of Tagged Polar Bears}

Although the location of capture of individuals in Area 5 was significantly influenced by the sex of the bear $\left(\mathrm{F}_{1,1631}\right.$ $=155.9, p<0.001)$ and the year $\left(\mathrm{F}_{17,1631}=16.8, p<0.001\right)$, it was not related to any ice chronology variables or interaction with these variables ( $p>0.05$ in all cases). Adult males tended to be caught in more northerly locations than adult females (Table 4). Although there was significant annual variation in the location of capture, there was no evident trend over time $\left(\mathrm{r}_{\mathrm{s}}=-0.018, \mathrm{n}=1667\right.$, $p=0.467)$.

Both male and female adult polar bears captured in Manitoba and Ontario showed a high degree of fidelity over time to locations on shore (Table 5). Of 1386 captures and recaptures of bears that were first caught in Area 5, only 11 recaptures took place in Ontario. Adult females showed a higher degree of fidelity than adult males $\left(\mathrm{F}_{1,1364}\right.$ $=20.9, p<0.001)$. The distance between two consecutive captures of the same individual was not influenced by the capture interval $\left(\mathrm{F}_{10,1364}=1.2, p=0.260\right)$, and this was true for both males and females, as there was no significant 'Sex $\times$ Capture Interval' interaction $\left(\mathrm{F}_{10,1364}=0.7, p=\right.$ $0.691)$. The mean distance between consecutive captures was $62.3 \pm 2.7 \mathrm{~km}$ for male bears $(\mathrm{n}=678)$ and $46.0 \pm 1.7$ $\mathrm{km}$ for female bears $(\mathrm{n}=708)$.

\section{DISCUSSION}

\section{Timing of Ice Breakup and Absence}

Our finding that the mean date of breakup of sea ice on western Hudson Bay became significantly earlier $(p=$ $0.0044)$ over 31 years (1971-2001) derived from an extension of the analysis of Stirling et al. (1999), which was based on the period 1979-98 and found a trend toward an earlier breakup that approached statistical significance $(p=0.07)$. During the late 1990s and early 2000s, the ice on western Hudson Bay broke up approximately three weeks earlier than it had done in the early 1970s. Not surprisingly, the trend to progressively earlier breakup was reflected in the results from Areas 4 and 5, which are subsamples of WH. As suggested by Stirling et al. (1999), this trend appears to be due to increasing mean spring temperatures over western Hudson Bay (Skinner et al., 1998) since atmospheric conditions, such as surface air temperatures, directly affect ice conditions in the bay
TABLE 5. Distance $(\mathrm{km})$ between consecutive capture locations of individual adult polar bears (188 males +236 females) handled between 1969 and 2000, in relation to the sex of the bear and the capture interval.

\begin{tabular}{crrrrrrr}
\hline \hline \multirow{2}{*}{$\begin{array}{c}\text { Capture Interval } \\
\text { (Years) }\end{array}$} & \multicolumn{3}{c}{$\begin{array}{c}\text { Males } \\
(188)\end{array}$} & & & \multicolumn{3}{c}{$\begin{array}{c}\text { Females } \\
(236)\end{array}$} \\
\cline { 2 - 4 } \cline { 6 - 8 } & Mean & SE & $\mathrm{n}$ & & Mean & SE & $\mathrm{n}$ \\
\hline 1 & 64.8 & 7.2 & 153 & & 49.8 & 5.8 & 108 \\
2 & 70.6 & 6.8 & 120 & & 49.1 & 4.9 & 121 \\
3 & 52.5 & 5.4 & 104 & & 43.3 & 4.1 & 100 \\
4 & 61.9 & 7.9 & 76 & & 45.7 & 4.7 & 76 \\
5 & 39.7 & 5.0 & 43 & & 44.7 & 4.5 & 72 \\
6 & 62.8 & 9.1 & 45 & & 38.4 & 3.5 & 59 \\
7 & 66.9 & 11.8 & 33 & & 45.4 & 4.6 & 44 \\
8 & 57.4 & 8.0 & 26 & & 44.9 & 7.7 & 40 \\
9 & 65.2 & 16.0 & 26 & & 40.7 & 4.5 & 33 \\
10 & 81.5 & 13.3 & 19 & & 42.6 & 6.2 & 21 \\
$\geq 11$ & 67.4 & 11.4 & 33 & & 56.5 & 5.5 & 34 \\
Combined & 62.3 & 2.7 & 678 & & 46.0 & 1.7 & 708 \\
\hline \hline
\end{tabular}

(Manak and Mysak, 1989; Etkin, 1991). A more detailed study of sea ice in the circumpolar Arctic by Parkinson et al. (1999) documented a $1.8 \%$ decrease per decade in the annual extent of sea ice on Hudson Bay from November 1978 through December 1996. The greatest decrease, $5.4 \%$ per decade, occurred during the summer months (July-September).

The absence of a similar trend toward earlier breakup off the Ontario coast, either in the whole of SH or in Areas $1-3$, may be related to a gradual cooling trend in eastern Hudson Bay (Skinner et al., 1998) and the Labrador Sea (Parkinson, 2000), or to the currents and prevailing northwest winds, which force the remaining sea ice to accumulate in Areas 1-3 each year (Wang et al., 1994; Saucier et al., in press).

\section{Population Trends as Indicated by Coastal Surveys}

The survey data from Manitoba showed an increase in the number of bears from the mid-1960s to the mid-1970s, after which the trend appeared stable, albeit with interannual variability. Although population data based on mark-recapture studies prior to the late 1970s were not as quantitative as those collected in later years, Derocher and Stirling (1995) reviewed available information from surveys, mean age of specimens collected from the Inuit harvest from 1966 through 1992, anecdotal information, and quantitative mark-recapture studies between the late 1970s and early 1990s. They concluded that the WH population had 
been overharvested by the mid- to late 1960s as a consequence of a number of factors, including (1) the active trading of polar bear hides at the Hudson's Bay Company's post at York Factory until it closed in 1957; (2) the killing of unrecorded numbers of polar bears by military personnel based at Churchill during the period that the base was in operation (1942-64); and (3) the absence of quotas regulating the polar bear harvest by hunters from Inuit settlements along the coast of western Hudson Bay north of Churchill until 1968. Thus, we suggest that although the coastal counts do not indicate the size of the population, they accurately reflect the population trend of recovery from overharvest through to relative stability.

In contrast, the Ontario survey data suggest an increase in numbers through 1996, when the last survey was flown. Interpreting the survey results from Ontario is more difficult because there are no independent sources of population data, like those from Manitoba, with which to make comparisons. The period over which quantitative markrecapture studies were done to estimate population on the Ontario coast (1984-86; Kolenosky et al., 1992) was too short to provide an indication of trend. However, because of the consistency between the results of the coastal surveys and independent data from Manitoba, we suggest that the consistent long-term trend of increasing numbers on the Ontario coast is real. A population increase in the $\mathrm{SH}$ population may in part be a response to reduced harvest pressure. From 1970-71 to 1989-90, the recorded Ontario harvest averaged 20.8 animals per year. From 1990 91 to $2000-01$, that average annual harvest was only 8.8 bears (M. Obbard unpubl. data), while the total annual harvest (by hunters from Nunavut, Quebec, and Ontario) recorded for SH since 1991 has fluctuated between about 40 and 48 animals (Lunn et al., 1998, 2002).

Lastly, the strong difference in the coastal population trends of polar bears in Manitoba (stable) and Ontario (increasing) also supports previous conclusions that the populations in the two areas are independent (Derocher and Stirling, 1990; Kolenosky et al., 1992; Taylor and Lee, 1995; Lunn et al., 1997; Stirling et al., 1999). Thus, although the coastal counts do not indicate the absolute size of either the $\mathrm{WH}$ or $\mathrm{SH}$ polar bear population, the trends in numbers provide area-specific indices. Since these indices have shown a high degree of independent consistency over more than three decades, we suggest that the counts accurately reflect the status of the populations in the two areas.

\section{Capture Locations and Movements of Tagged Bears}

Individual bears showed a high degree of fidelity over time to their summering areas. The area in which the Western Hudson Bay population spends the open water season exceeds $12000 \mathrm{~km}^{2}$ and includes over $600 \mathrm{~km}$ of coastline. Yet the average distance between consecutive terrestrial capture locations of the same individual, over intervals of 1 to 11 or more years, was only $62 \mathrm{~km}$ for adult males and $46 \mathrm{~km}$ for adult females. Clearly, bears return to specific areas regardless of where they come ashore.

The importance of the small, but statistically significant, difference in the mean distance between captures of males and females is unclear. Similarly, in Area 5, adult males were captured significantly farther north than adult females, although the difference in mean latitude of capture was only $28 \mathrm{~km}\left(0.252^{\circ}\right.$ latitude). Adult females may simply show a higher degree of fidelity to specific areas than males when they come ashore to fast during the open water season. Analysis of where and when adult females fitted with satellite collars came ashore indicated a close relationship with the time of breakup (Stirling et al., 1999) and suggests that coming ashore in a particular place is more important than remaining on the ice for a longer time, especially if staying longer means moving farther from where they eventually wish to spend the summer. For pregnant females, coming ashore close to a preferred inland denning area would minimize the energetic costs of travel to find a den. It is less clear why females accompanied by cubs should show as high a degree of fidelity to the same area of the coast, though this could be an effective mechanism to teach female offspring the location of inland denning areas. Where males come ashore may be less critical, since for the most part they simply aggregate on points, raised coast beaches, and small offshore islands where ambient temperatures are coolest throughout the fasting period. Thus, the exact location of coming ashore likely has less energetic significance for males than it does for females, which may partially explain the greater average distances between the males' capture and recapture sites.

\section{Influence of the Timing of Ice Breakup and Absence on Survey Counts}

Neither the timing of ice breakup nor ice absence significantly increased the explanatory power of multiple regression models describing the numbers of polar bears counted on coastal surveys when the term was entered alone. However, both were important when included as part of an interaction with other variables or when used as part of a calculated variable. Ice breakup was included in the two interaction terms of the Manitoba model that explained $79.2 \%$ of the variance, but it was not included in the Ontario model. Ice absence, although part of the interaction term that explained $34.6 \%$ of the variance in the Manitoba model, was more important in the Ontario model, where it was included in all three terms that together explained $71.6 \%$ of the variance.

Why the relative importance of ice breakup and ice absence varied between the Manitoba and Ontario surveys is uncertain. However, we suggest the difference may be related to energy expenditure and fidelity of polar bears to onshore areas. The last remaining ice on Hudson Bay occurs off the coast of Ontario, where it breaks up and disintegrates about two weeks later than the ice off the 
Manitoba coast between York Factory and Hubbart Point (Area 5). For the WH population, the energetic costs of remaining on the ice for an additional two weeks of hunting and then walking several hundred kilometres back to preferred summering or maternity denning areas in Manitoba, without access to food, may be greater than the energetic costs of simply coming ashore earlier and fasting. By contrast, because the prevailing winds and currents cause the last remnants of ice to accumulate off the coast of Ontario in most years (Markham, 1986; Wang et al., 1994; Saucier et al., in press), ice absence may be more important than ice breakup in determining when the Southern Hudson Bay population comes ashore. Bears that remain on the ice longer after breakup may not have to move much after coming ashore to be where they prefer to spend the summer.

In eight different years on the Ontario coast, Prevett and Kolenosky (1982) repeated their surveys over the same route in the same year but about one month later. In seven of the eight years, the proportions of bears were lower in Areas 2 and 3, while they had increased in Area 1, indicating that in most years, bears tend to move east out of Areas 2 and 3 into Area 1. The one exception was 1968, when the proportion of bears decreased in Areas 1 and 2 but increased in Area 3. Similarly, in 1981 and 1984, when the ice absence patterns were similar, but there was a twoweek difference in the survey dates, more bears were sighted in Area 1 than in Area 3 on the later survey. Possible reasons for the bears to move east toward Cape Henrietta Maria include better conditions for summering or, more likely, that such movements put the bears closer to the areas where they hunt seals after freeze-up. The latter interpretation is supported by the findings of Kolenosky et al. (1992), which showed that radio-collared bears traveled north and northeast after freeze-up and that most tagged bears shot by hunters were also killed to the northeast, in the Belcher Islands.

In Manitoba, fall movements of bears north along the coast toward Cape Churchill (in the northern portion of Area 5) have been documented in previous studies and attributed to earlier freeze-up there than elsewhere, which enables bears to return to the ice to hunt seals as soon as possible (Stirling et al., 1977; Derocher and Stirling, 1990). When bears first depart onto the sea ice from the coast after freeze-up, they travel north and northeast as well, as do females leaving the denning area in the spring (Stirling et al., 1977; Ramsay and Andriashek, 1986; Derocher and Stirling, 1990). Thus, it appears that the movement of bears during the fall northward through Areas 4 and 5 and eastward from Areas 2 and 3 to Area 1 is ecologically based and related to time of freeze-up. Furthermore, this pattern of movements by bears in Manitoba and Ontario through the open water period when they are fasting on land also helps to keep the populations separate during that time.

In summary, our evaluation of annual counts of polar bears along the coasts of Manitoba and Ontario in late
August and early September, along with independent data on the movements of tagged bears and annual patterns of ice breakup and absence, indicates that (1) the coastal survey data reliably indicated the population trend, though not the abundance of polar bears, in each population; and (2) the timing of ice breakup and absence influences the distribution of bears on the coastline of each province, independently of the other.

\section{ACKNOWLEDGEMENTS}

We thank the following for their support of our long-term studies of the population ecology of polar bears in western and southern Hudson Bay: Canadian Wildlife Service, Manitoba Conservation, Ontario Ministry of Natural Resources, Natural Sciences and Engineering Research Council, World Wildlife Fund (Canada), Nunavut Wildlife Management Board, Parks Canada Agency, and the Polar Continental Shelf Project. We are also very grateful to the numerous pilots and observers who participated in the annual coastal counts and to Sam Barry for statistical discussions.

\section{REFERENCES}

AMSTRUP, S.C., and GARDNER, C. 1994. Polar bear denning in the Beaufort Sea. Journal of Wildlife Management 58:1-10.

CLARK, D.A., and STIRLING, I. 1998. Habitat preferences of polar bears in the Hudson Bay lowlands during late summer and fall. Ursus 10:243-250.

DEROCHER, A.E., and STIRLING, I. 1990. Distribution of polar bears (Ursus maritimus) during the ice-free period in western Hudson Bay. Canadian Journal of Zoology 68:1395-1403. 1995. Mark-recapture estimation of population size and survival rates for polar bears in western Hudson Bay. Journal of Wildlife Management 59:215-221.

DEROCHER, A.E., ANDRIASHEK, D., and STIRLING, I. 1993. Terrestrial foraging by polar bears during the ice-free period in western Hudson Bay. Arctic 46:251 - 254.

ETKIN, D.A. 1991. Break-up in Hudson Bay: Its sensitivity to air temperatures and implications for climate warming. Climatological Bulletin 25(1):21 - 34 .

JONKEL, C., SMITH, P., STIRLING, I., and KOLENOSKY, G.B. 1976. Notes on the present status of the polar bear in James Bay and the Belcher Islands. Canadian Wildlife Service Occasional Paper No. 26. 41 p.

KOLENOSKY, G.B., ABRAHAM, K.F., and GREENWOOD, C.J. 1992. Polar bears of southern Hudson Bay. Polar Bear Project, 1984-88. Final Report. 107 p. Available from: Wildlife Research and Development Section, Ontario Ministry of Natural Resources, 300 Water St., 3rd Floor N, Peterborough, Ontario K9J 8M5, Canada.

LUNN, N.J., STIRLING, I., ANDRIASHEK, D., and KOLENOSKY, G.B. 1997. Re-estimating the size of the polar bear population in western Hudson Bay. Arctic 50:234-240.

LUNN, N.J., TAYLOR, M., CALVERT, W., STIRLING, I., OBBARD, M., LAMONTAGNE, G., SCHAEFFER, J., 
ATKINSON, S., CLARK, D., BOWDEN, E., and DOIDGE, B. 1998. Polar bear management in Canada 1993-1996. In: Derocher, A.E., Garner, G.W., Lunn, N.J., and Wiig, Ø., eds. Polar Bears: Proceedings of the 12th Working Meeting of the IUCN/SSC Polar Bear Specialist Group, 3-7 February 1997, Oslo, Norway. Occasional Paper of the IUCN Species Survival Commission No. 19. Cambridge: IUCN Publication Services. $51-66$.

LUNN, N.J., ATKINSON, S., BRANIGAN, M., CALVERT, W., DOIDGE, B., ELLIOTT, C., NAGY, J., OBBARD, M., OTTO, R., STIRLING, I., TAYLOR, M., and VANDAL, D. 2002. Polar bear management in Canada 1997-2000. In: Lunn, N.J., Schliebe, S., and Born, E.W., eds. Polar Bears: Proceedings of the 13th Working Meeting of the IUCN/SSC Polar Bear Specialist Group, 23-28 June 2001, Nuuk, Greenland. Occasional Paper of the IUCN Species Survival Commission No. 26. Cambridge: IUCN Publication Services. 41-52.

MANAK, D.K., and MYSAK, L.A. 1989. On the relationship between Arctic sea-ice anomalies and fluctuations in northern Canadian air temperature and river discharge. AtmosphereOcean 27:682-691.

MARKHAM, W.E. 1986. The ice cover. In: Martini, I.P., ed. Canadian inland seas. Amsterdam: Elsevier Science Publishers B.V. $101-116$.

PARKINSON, C.L. 2000. Variability of Arctic sea ice: The view from space, an 18-year record. Arctic 53:341-358.

PARKINSON, C.L., CAVALIERI, D.J., GLOERSEN, P., ZWALLY, H.J., and COMISO, J.C. 1999. Arctic sea ice extents, areas, and trends, 1978-1996. Journal of Geophysical Research 104 (C9):20837-20856.

PREVETT, P., and KOLENOSKY, G.B. 1982. The status of polar bears in Ontario. Le Naturaliste Canadien (Revue d'Écologie et de Systématique) 109:933-939.
PRINSENBERG, S.J., and FREEMAN, N.G. 1986. Tidal heights and currents in Hudson and James Bay. In: Martini, I.P., ed. Canadian inland seas. Amsterdam: Elsevier Science Publishers B.V. 205-216.

RAMSAY, M.A., and ANDRIASHEK, D.S. 1986. Long distance route orientation of female polar bears (Ursus maritimus) in spring. Journal of Zoology (London) 208:63-72.

RAMSAY, M.A., and STIRLING, I. 1990. Fidelity of polar bears to winter den sites. Journal of Mammalogy 71:233-236.

SAUCIER, F.J., SENNEVILLE, S., PRINSENBERG, S., SMITH, G., GACHON, P., CAYA, D., and LAPRISE, R. In press. Modeling the ice-ocean seasonal cycle in Hudson Bay, Foxe Basin and Hudson Strait, Canada. Climate Dynamics.

SKINNER, W.R., JEFFERIES, R.L., CARLETON, T.J., ROCKWELL, R.F., and ABRAHAM, K.F. 1998. Prediction of reproductive success and failure in lesser snow geese based on early season climatic variables. Global Change Biology 4:3-16.

STIRLING, I., and DEROCHER, A.E. 1993. Possible impacts of climatic warming on polar bears. Arctic 46:240-245.

STIRLING, I., JONKEL, C., SMITH, P., ROBERTSON, R., and CROSS, D. 1977. The ecology of the polar bear(Ursus maritimus) along the western coast of Hudson Bay. Canadian Wildlife Service Occasional Paper No. 33. 64 p.

STIRLING, I., LUNN, N.J., and IACOZZA, J. 1999. Long-term trends in the population ecology of polar bears in western Hudson Bay in relation to climatic change. Arctic 52:294-306.

TAYLOR, M., and LEE, J. 1995. Distribution and abundance of Canadian polar bear populations: A management perspective. Arctic 48:147-154.

WANG, J., MYSAK, L.A., and INGRAM, R.G. 1994. A numerical simulation of sea ice cover in Hudson Bay. Journal of Physical Oceanography 24:2515-2533. 